\title{
Research Paper \\ Prediction of Psychological Distress based on Cognitive Emotion Regulation and Adaptive Strategies in Mothers of Children with Thalassemia
}

Leila Haghshenas ${ }^{* 1}$

1. M.A. in Psychology, Faculty of Humanities, Payame Noor University, Tehran, Iran

Citation: Haghshenas L. Prediction of psychological distress based on cognitive emotion regulation and adaptive strategies in mothers of children with thalassemia. Quarterly Journal of Child Mental Health. 2019; 6(3): 89-100.

\section{http://dx.doi.org/10.29252/jcmh.6.3.9}

\section{A R T I C L E I N F O}

\section{Keywords:}

Psychological distress, cognitive emotion regulation strategies, adaptive strategies, thalassemia

Received: 25 May 2018 Accepted: 6 Oct 2018 Available: 9 Nov 2019

\section{A B S T R A C T}

Background and Purpose: Thalassemia is a chronic childhood illness that can negatively affect the psychological well-being and life quality of the children and their families. This study was conducted to predict the psychological distress based on cognitive emotion regulation and adaptive strategies in the mothers of children with thalassemia.

Method: This study was descriptive- correlational research . The study population included the mothers of children with thalassemia in Tehran. 250 of these mothers them were selected by convenience sampling method as the study sample. Data were collected by Lovibond's Psychological Distress Scale (1995), Cognitive Emotion Regulation Scale (Garnefski, 2001) and Coping Strategies Questionnaire (Lazarus, 1974). Data were analyzed by Pearson correlation and multiple regression. Results: The results of the data analysis indicated a significant and positive effect of negative emotion regulation strategies on anxiety $(0.14)$ and the negative significant effect of positive emotion regulation strategies on depression $(-0.25)$ and anxiety $(-0.23)$. Also, adaptive strategies were effective on psychological distress. The effect of emotion-focused strategy on anxiety $(0.23)$ and stress $(0.19)$ were positively significant, while the effect of problem-focused adaptive strategies on depression $(-0.18)$ and stress $(-0.2)$ was negatively significant $(\mathrm{P}<0.01)$.

Conclusion: The cognitive emotion regulation strategies and adaptive strategies affected the psychological distress among mothers of children with thalassemia. The implications of the results are discussed in the paper.

\footnotetext{
* Corresponding author: Leila Haghshenas, M.A. in Psychology, Faculty of Humanities, Payame Noor University, Tehran, Iran.

E-mail addresses: Lhaghshenas58@yahoo.com
} 


\section{يبش بينى درماند كى روانشناختى بر اساس تنظيم شناختى هيجان و راهبردهاى انطباقى در مادران كود كان مبتلا به تالاسمى ليلا حقشناس \\ ا. كارشناس ارشد روانشناسى، دانشكده علوم انسانى، دانشكاه بيام نور، تهران، ايران}

\begin{tabular}{|c|c|}
\hline جكيده & 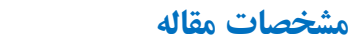 \\
\hline زمينه و هدف: تالاسمى يكك بيمارى مزمن دوران كو دكى است و مى تواند بر سلامت روانى و كيفيت زند گى كود كان و خانو ادههاى آنها & 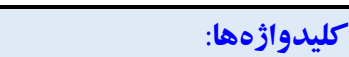 \\
\hline تأثير منفى بكذارد. اين مطالعه با هدف يِيشيينى درماند گى روانشـناختى بر اسـاس تنظيم شـناختى هيجان و راهبردهاى انطباقى در مادران & 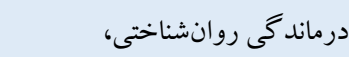 \\
\hline 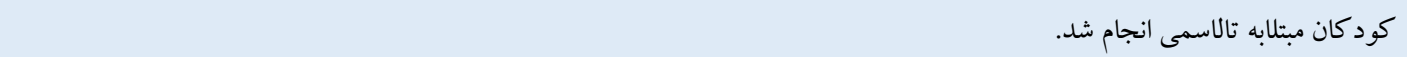 & 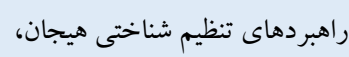 \\
\hline روش: اين مطالعه به روش توصيفى و از نوع همبستخى بود. جامعه آمارى يُوهش حاضـر مادران كود كان مبتلابه تالاسمى شهر تهران بود & 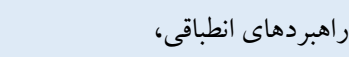 \\
\hline كه از بين آنها • •هr نفر بهصورت نمونه گيرى در دسترس بهعنوان نمونه برزوهش انتخاب شـدهاند. دادهها با استفاده از برسششنامه درماندكى & تالاسمى \\
\hline روانشـناختى (لويبوند و لو يبوند، 199ه)، بِرسـشـنامه تنظيم شـناختى هيجان (كارنفسـحى، كرايج و اسـينهاون، ، 2001)، و برسـشـنامه & \\
\hline 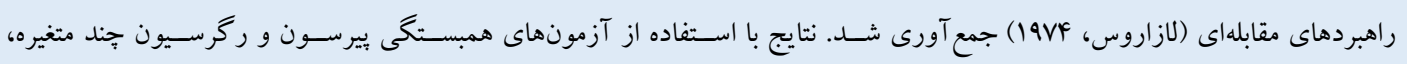 & \\
\hline ت تجزيهوتحليل شد. & \\
\hline 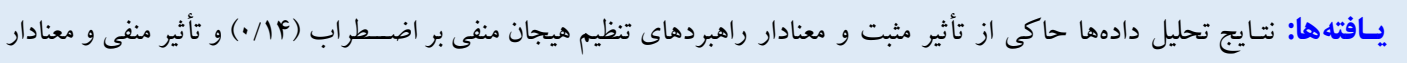 & \\
\hline 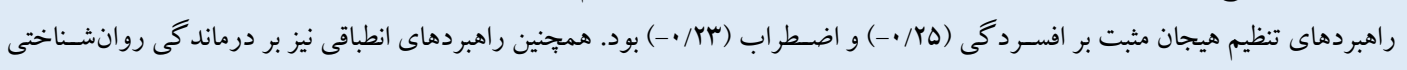 & \\
\hline مؤثر بودند. تأثير راهبرد هيجانمدار بر اضطراب (سr/•) و بر تنيدگى (19/•)، مثبت و معنادار، و تأثير راهبرد انطباقى مسئله مدار بر افسردگى & \\
\hline ) & 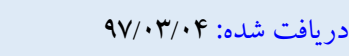 \\
\hline نتيجه كيرى: بر اسـاس نتايج مطالعه حاضـر، آموزش راهبردهاى تنظيم شـناختى هيجان و راهبردهاى انطباقى بر درماند گى روانشــناختى & 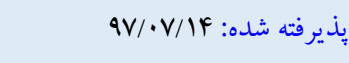 \\
\hline مادران كو دكان مبتلابه تالاسمى تأثير داشت؛ استلزامات نتييجه به دست آمده در مقاله مورد بحث و تبيين قرار كرفته است. & 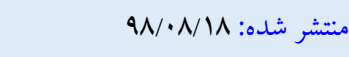 \\
\hline
\end{tabular}

* نويسنده مسئول: ليلا حقشناس، كارشناس ارشد روانشناسى، دانشكده علوم انسانى، دانشكاه بيام نور، تهران، ايران.

رايانامه: Lhaghshenas58@yahoo.com 
مقـابلـهاى شــــاختى و رفتـارى كه فرد هنكام مواجهه با موقعيت هاى

مقدمه

تنيـدگىها به كار مىبندد، در تعيين ميزان تهديد و درماندگى كه آن موقعيت برحسـب بيامدهاى روانى و جسـمانى براى فرد ايجاد مى كند،

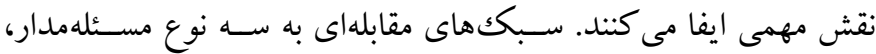
هيجانمدار، و اجتنابمدار تقسيم مىشـود. سبكك مقابلهاى مسئلهمدار به رفتارها و شـناختهايى كه هدف آنها تغيير موقعيت يا متغير تنش آور اسـت اطلاق مىشود. سبك مقابلهاى هيجانمدار، رفتارها و شناختهايى را شـامل مىشـود كه در آن هدف، تغيير پياسـخ فرد به عامل تنش آور

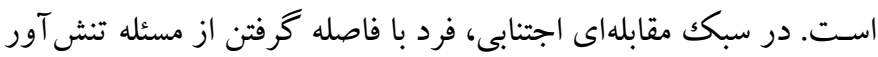
از آن فرار مى كند و در جستجوى حمايت عاطفى و واكذارى مسئوليت مقابله به اطرافيان اسـت. در همين راستا در بذزوهشى بن - زور (9) رابطؤ

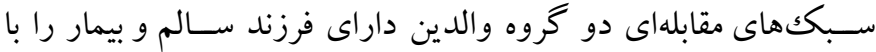
بهزيسـى روانى آنان مورد بررسى قرارداد. نتايج نشـان داد بين سـبك تسك مقابله و بهزيستى روانى والدين در دو گرروه رابطه وجود داشت. همجِنين والدين داراى سبكك مقابلة مسئلهمدار، بهزيستى روانى بالايى نشان دادند

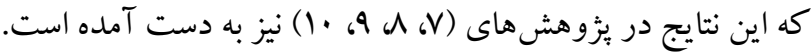
از آنجـايى كـه والـدين كودكـان مبتلـابه تالاسـمى طيف وسـيعى از

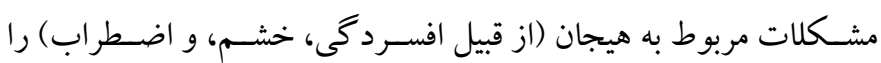

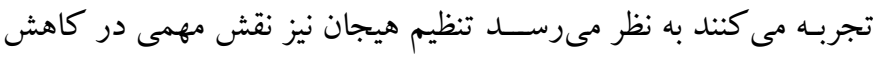

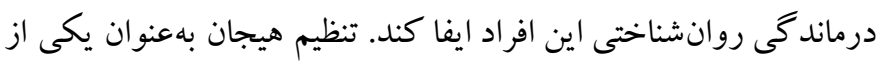
تعديل كنندههاى فردى قوى، يِيشينى كننده سـامت روان اسـت. تنظيم هيجان به راهبردهايى اطلاق مىشـود كه بهمنظور كاهش، افزايش، يا نخهـدارى تجارب هيجانى مورد اســفاده قرار مى گيرد (1). به باور

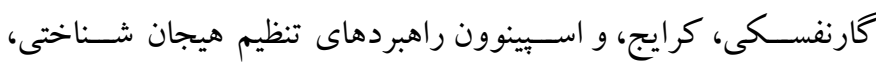
كنشهايى در رابطه با راههاى كنار آمدن فرد با شـــايط تنش آور و يا

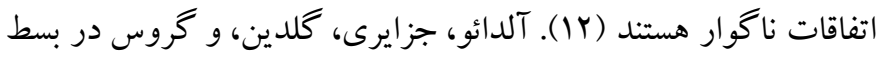
نظريههاى مربوط به راهبردهاى تنظيم هيجانى، اظهار داشتند كه اختلال و

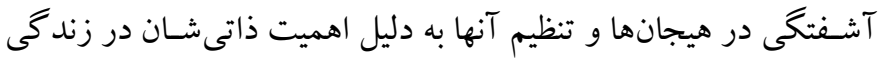

بيمارى تالاسـمى' يكك كمخونى هموليتك مادرزادى مزمن اسـت و در كشـورهاى نواحى درياى مديترانه نظير ايتاليا، يونان، قبرس، لبنان و ايران

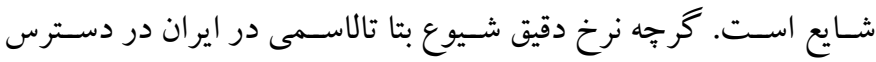

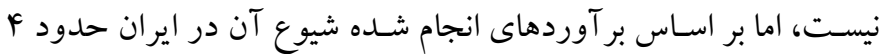

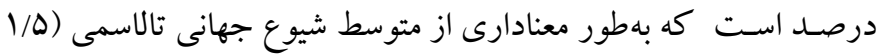
درصــد) بالاتر اسـت (1). بتا تالاسـمى بهعنوان يكك بيمارى مزمن، تأثير زيـادى بر ســلـامـت جسـمى و روانى والدين دارد كه مىتواند كيفيت زندگى آنها را كاهش دهد (Y)؛ جرا كه همانند هر بيمـارى مـزمن ديخر علاوه بر عوارض جسمى سبب برخى مشكلات روانسـى و اجتماعى براى بيمـاران و خـانو ادههــــ آنها نيز مسى شود كـه از ماهيت و سير بيمارى منشأ مى گيرد. اين بيمارى در سال اول تولد، تأثيرات جشمخيرى بر فرايند تحول و تكامل دارد. رشـــ جسـمى كودكك مبتلابه تالاسـمى كمتر از همسـالان آنها اسـت كه احسـاسـاتى از قبيل كهترى، متفاوت بودن، و يا نداشتن شايستخى انجام كارهاى مربوط به آن سن را به وجود مى آورد و موجب مشكلاتى در مراقبت از خود و كيفيت زندگى شـان مىشود (r). تشـخيص بيمارى تالاسـمى مانند هر بيمارى مزمن و محدود كننده ديخر تأثير نامطلوب بر سلامت روانى بيمار و خانواده او خو اهد داشت. بسيارى از اين والـدين بـه نحوى دجار حالاتى جون افسـردگى، اضـطراب، برخاشـحرى، ترس، خجالت، آرزوى مرگك، و نظاير آن مى شـوند كه مجموعاً درماندگى روانشناختى را تشكيل مى دهند (F).

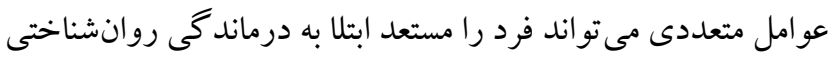

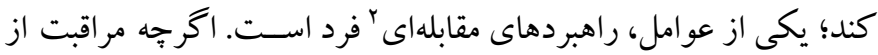

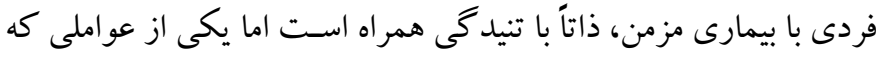

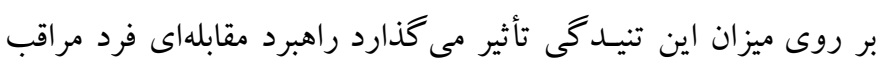
است (r). هيجانات و برانگيختخى فيزيولوزيكك ايجاد شده براثر موقعيت

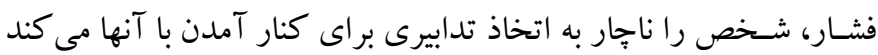
كـه تحـت عنوان راهبرد مقـابله، از آنها ياد مىشــود (ه). راهبردهاى 
تنيدگى بيشترى را تجربه كرده و نياز به مهار و تنظيم هيجانات و همجنين استفاده از راهبردهاى انطباقى مناسب جهت فائق آمدن بر مشكلات ناشى از حضور فرزند بيمار در خانواده، در آنها بيشتر است. در حقيقت وجود

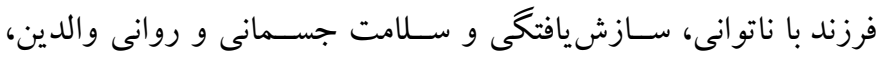
بهخصوص مادران را تهلديد كرده و بر بر بهزيستى روانى آنها تأثير منفى ونى دارد (YI). با توجه به اين كه در كشور ما مادران مراقبان اصلى كود كان

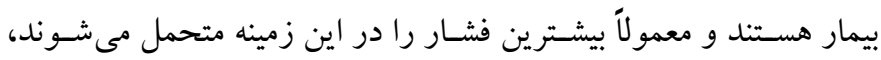
نتايج اين بزوهش مى تواند باعث فزونى دانش يثزوهشـخران در راسـتاى بهبود مداخلات مربوط بهسـلامت مراقبين كود كان مبتلابه تالاسمى شود و در نهايت به شــرايط مراقبتى مطلوب در زندكى كود كان منجر شـود؛؛ بنابر اين براساس آنجه در مورد اهميت تنظيم شناختى هيجان و راهبردهاى انطباقى كار آمد در بهبود سلامت روان در بيشينه نظرى و يُوهشى مطرح شد، مسئله اصلى يُزوهش حاضر اين است كه آيا تنظيم شناختى هيجان و راهبردهاى انطباقى مى تو اند درماندگى روانشـناختى در مادران كود كان

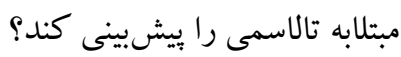

روش طرح يثووهش و شــركت كنند كان: اين مطالعه به روش توصـيفى و از نوع همبسـتخى اسـت. جامعه آمارى اين بثزوهش شـامل تمامى مادران كود كان مبتلابه تالاســمى مراجعه كننده به مراكز درمانى شــهر تهران (بيمارسـتان مفيد، حضـرت على اصسغر، و مر كز طبى كود كان) در سـال

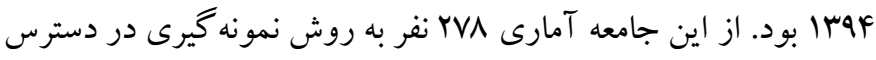

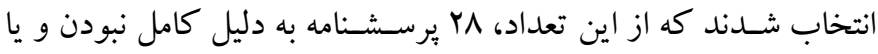

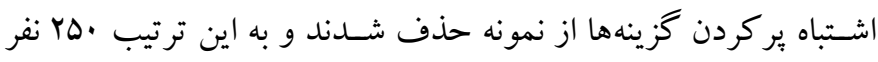
بهعنوان نمونه وارد يثزوهش شـدند. ملاككهاى ورود به بزروهش عبارت بودند از: دامنه سـنى كودكك بين متا • إل، ابتلا به تالاسمى مازور، و

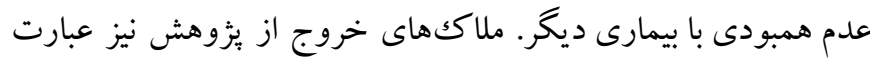
بودند از: نداشـتن تابعيت ايرانى مادران، و داشـتن سـابقه مداخلات

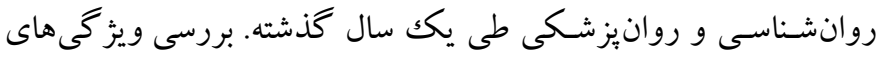

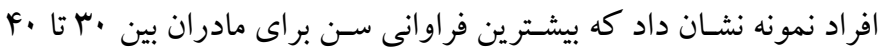

روزمره، يِيامدهاى آسيبشناختى معنادارى خو اهند داشت (r|). اهميت مهارت تنظيم هيجان براى حفظ ســامت روان در يزوهش هاى زيادى تأييد شده است (11، سا-19). اشكال در تنظيم و مهار هيجانات منفى، با اختلالات دروننمود مانند اضطراب و افسردگى ارتباط دارد. اخيراً برخى يُزوهشـخران، مطالعات گسـتردهاى درباره ارتباط بين ابراز گرى هيجانى، مهار هيجانى، و دوسو گرايى در ابراز هيجان با ابعاد مختلف سلامت انجام

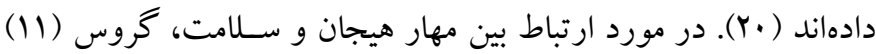
معتقد اسـت، كه بازدارى هيجانى با كاهش تندرسـى همبسـته اسـت. در همين راستا عزيزى و همكاران در يزوهشى به بررسى رابطه مهار هيجان

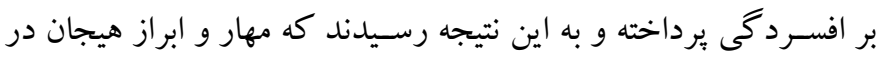

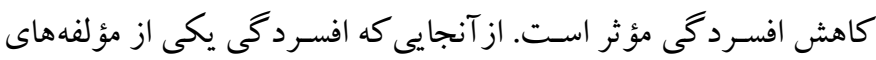

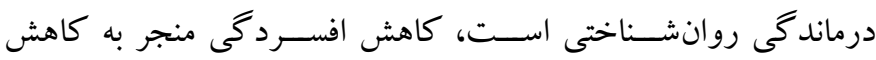

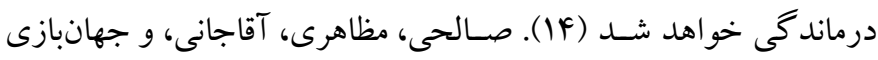
(10) و همجِين بهر امى، بهرامى، مشهـدى، و كارشكى (19) در بررسى نقش راهكارهاى مهار شــناختى هيجان در كيفيت زندگى به اين نتيجه رسـيدند كه راهكارهاى تمركز مجدد مثبت، ارزيابى مجدد مثبت، و ديد گاه گيرى با كيفيت زندگى رابطه مثبت معنادار دارند؛ در حالى كه

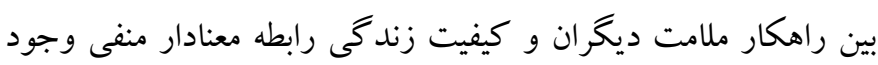
دارد. به اين ترتيب ملاحظه مىشــود كه بين افسـردگى، اضـطراب، و

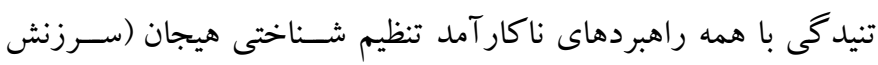
ديخران، ســرزنش خود، نشــخوار فكرى، فاجعه يُندارى، و يذيرش)

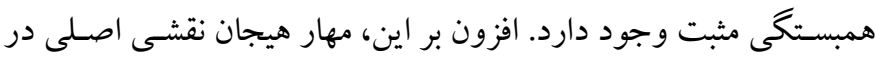
تحول بهنجار داشـته و ضسف در آن، عاملى مهم در ايجاد آسـيبهاى روانى به شمار مىرود. به همين دليل متخصصان معتقدند افرادى كه قادر به مديريت صسحيح هيجاناتشـان در برابر وقايع زندكى نيسـتند، بيشـتر از

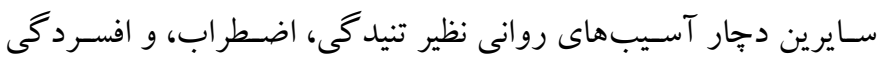
مىشوند كه در نهايت به درماندگى روانشناختى منجر مى شود. بر اسـاس بثزوهش هاى انجام شــده، مادران داراى كود كان با نيازهاى ويزه در مقايسه با پدران با مشكلات بيشترى مواجه مى شوند و با مشكلات رفتارى فرزند خود بيشـتر كلنجار مىروند. به همين دليل مادران سـطح 
مى گيرد. ضـريب آلفاى كرونباخ براى خردهمقياس هاى اين برسـشـامه

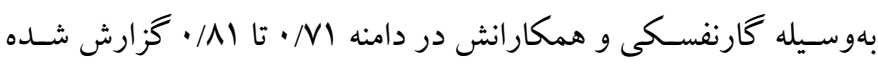
اسـت. در مطالعه بشـارت نيز ضـرايب آالفاى كرونباخ بين 9V/ • تا ه9/. • كزارش شـد (به نقل از V). بهعلاوه، روايى همزمان برسـشـنامه از طريق

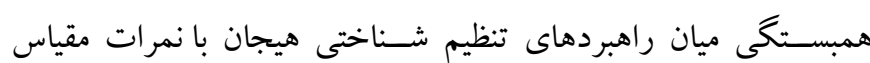

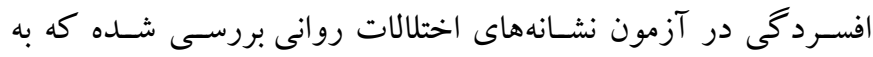
ترتيب راهبردهاى فاجعهبار خواندن (هذه/•)، نشـخوار فكرى ( •ه/•)،

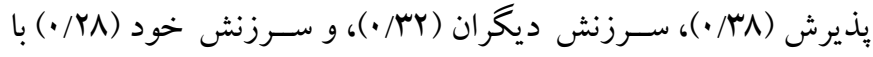

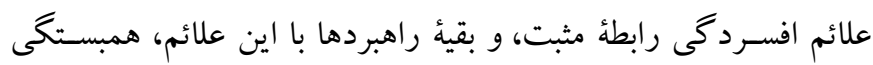
منفى داشتند (1) (1).

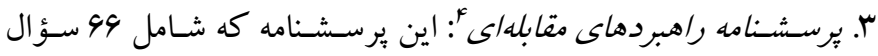
است، توسط لازاروس (19VF) ساخته شده است و دو راهبرد هيجانمدار و مسئلهمدار را مورد سنجش قرار مىدهد. 19 عبارت اين آزمون انحر افى هستند و •ه عبارت ديخر شسيوه مقابله فرد را مورد ارزيابى قرار مىدهد. در اين برسشنامه خردهمقياس هاى راهبردهاى مسئلهدار شامل جستجوى حمايت اجتماعى، مسئوليتيذيرى، حل مدبر انه مسئله، و بازبر آوردمثبت؛

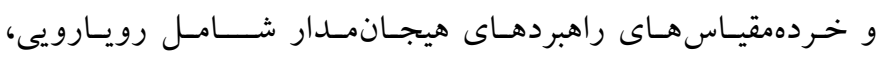

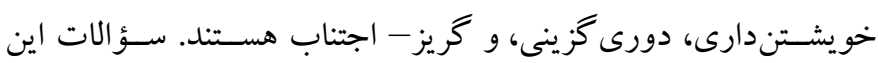
مقياس روى يـك طيف F درجهاى (از به كار نبردهام تا زياد به كار

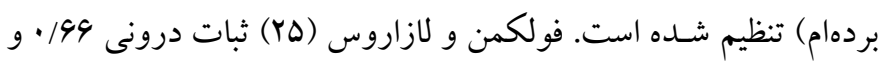

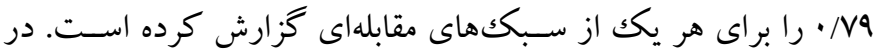

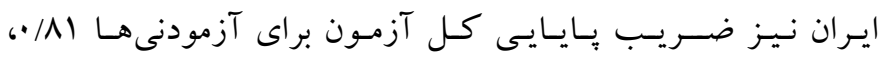

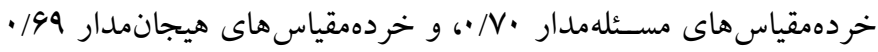

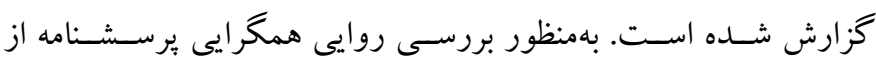
همبستخى نمرههاى خام حاصل از برسـنامه با نمرههاى خام حاصل از

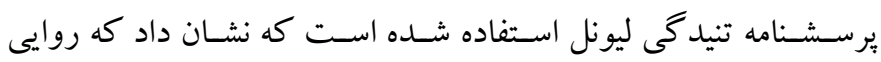
برسشنامه بسيار بالاست. همجنين نتايج تحليل مؤلفهاى اصلى و جرخش

3. Cognitive Emotion Regulation Scale

4. Coping Strategies Questionnaire

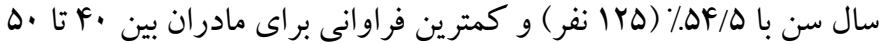

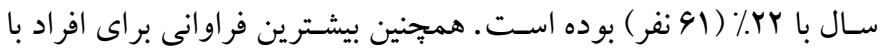
مدر كك تحصيلى فوقدييلم و كارشــاسى با 99/0٪ (4\& أنفر ) و كمترين فراوانى براى افراد با مدرك تحصيلى كارشـناس ارشد و بالاتر با ه/. 1\%

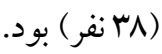

ب) ابزار: بهمنظور جمع آورى دادهها در اين ئزوهش، از ابزارهاى زير استفاده شده است. ا. درماندكى روانشـناختى': مقياس درماندگى روانشـناختى لويبوند و

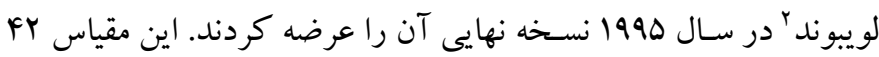
كويهاى براى سنجش افسردگى، اضطراب، و تنيدگى طراحى شده است و بر اساس طيف ليكرت \& درجهاى (1= بسيار زياد در مورد من درست

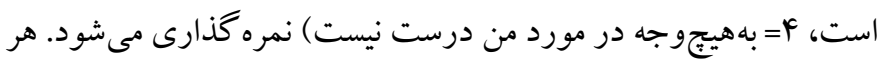

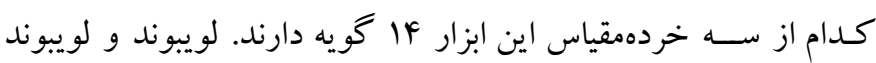
ضرايب همسانى درونى (آلفاى كرونباخ) سه خردهمقياس اين تست را به به

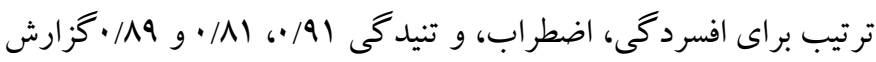
كردهاند (Yr). در ايران نيز اين مقياس توسط اصغرى، سائد و ديباجنيا

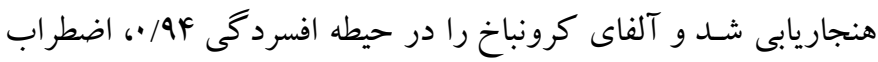

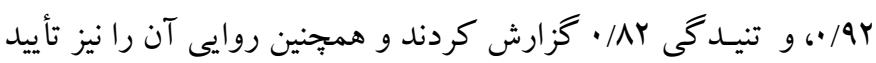

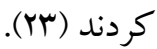
r. مقياس راهبردهاى تنظيم شسناختى هيجان": مقياس راهبردهاى تنظيم شـناختى هيجان توسط كارنفسكى، كرايج، و اسيينوون (T I) بهمنظور ارزيابى نحوه تفكر بعد از تجربه رخدادهاى تهديدكننده يا تنش آور زندكى تهيه شــده اسـت. اين مقياس از 9 خردهمقياس تشكيل شــده و

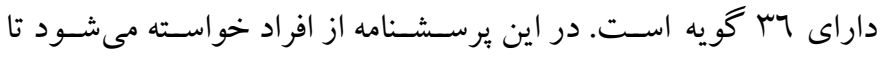
واكنش خود را در مواجهه با تجارب تهديدآميز و رويدادهاى تنش آور

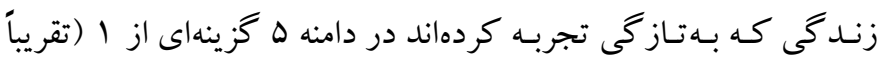

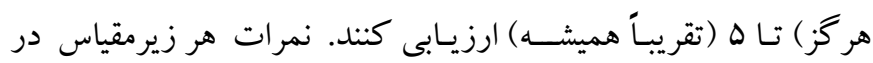

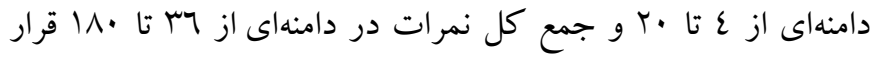

1. Psychological Distress Scale (DASS) and (Lazarus , 2. Lovibond 
اين مطالعه رعايت شد. در ياين يس از جمع آورى دادهها، تجزيه و تحليل

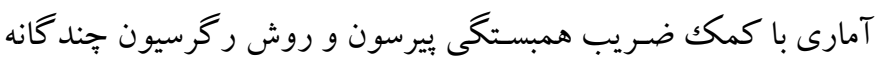

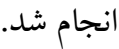

يافته ها

در يززوهش حاضـر •ro نفر از مادران كود كان مبتلابه تالاسـمى شـركت داشـتند كه نتايج مربوط شـاخص هاى آمار توصسيفى به همر اه جولكَى و كشيدگى در جدول إززارش شده است.
واريانس نشـان داد كه اين يرسشنامه از · اعامل با بار عاملى بيش از ஈ/.

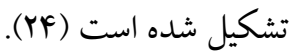
ج) روش اجرا: يس از اخذ مجوزهاى للازم، با مر اجعه حضورى به مراكز

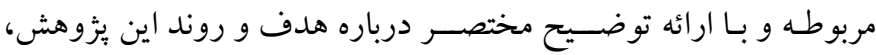
يرسـشــنهها در اختيار مادرانى كه رضـايت خود را براى همكارى ابراز

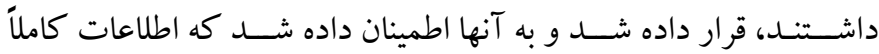

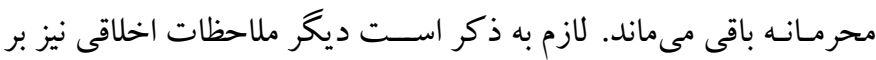
اسـاس تجويزات انجمن روانشناسى آمريكا و نظام روانشناسى ايران در

جدول ا: يافتهاى توصيفى خردهمقياس هاى تحقيق

\begin{tabular}{|c|c|c|c|c|}
\hline كشيدكى & جولكى & انحراف استاندارد & ميانغين & شاخص آمارى مقياس \\
\hline$\cdot / \mathrm{AV}$ & $-\cdot / V F$ & 1.1 .9 & $\Delta H / V Y$ & راهبرد هيجانمدار \\
\hline$\cdot / \mathrm{rr}$ & $-\cdot / M$ & $V / \cdot 9$ & $\$ 9 / .0$ & راهبرد مسئلهمدار \\
\hline • &.$- / 99$ & $f / r q$ & $F F / Y q$ & راهبردهاى تنظيم هيجان مثبت \\
\hline.$/ 9 F$ & $-\cdot / \mathrm{VV}$ & $9 / . r$ & $\Delta G / Y Y$ & راهبردهاى تنظيم هيجان منفى \\
\hline$\cdot / \mathrm{VA}$ & $-\cdot / 94$ & $\mathrm{~V} / \mathrm{VA}$ & $r Q / \Delta r$ & اضطراب \\
\hline.$/ 1 F$ & $-\cdot / \Delta 1$ & $9 / 9_{9}$ & rT/va & تنيدگى \\
\hline.$- / 19$ & $-\cdot / 4 q$ & $V / \cdot 9$ & $\$ 9 / .0$ & افسردگى \\
\hline
\end{tabular}

ضـرايب همبسـتكى جدول Y نشــان مىدهد كه از بين راهبردهاى

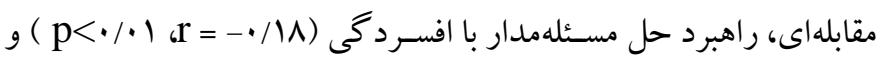

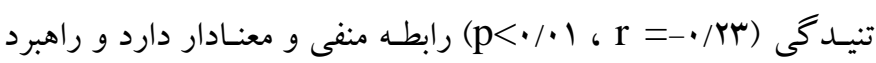

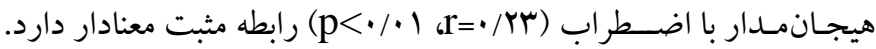
همجينين از بين راهبردهاى تنظيم هيجان، راهبرد تنطيم هيجان منفى رابطه

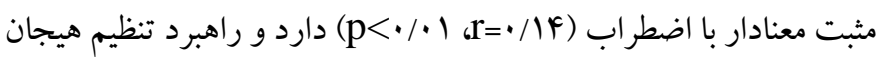

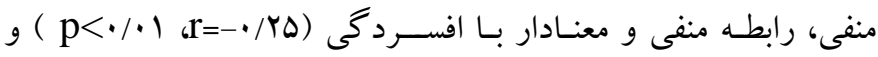

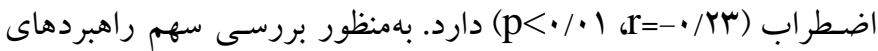
مقابلهاى و راهبردهاى تنظيم هيجان در تبيين درماندكى روانشـناختى، از تحليل ركرسـيون به روش كامبه كام اسـتفاده شـد كه نتايج آن به تفكيكك براى هر خرده مقياس در جداول سو أو ها گزارش شده است.
با توجه به دادههاى جدول ادر مقياس راهبردهاى انطباقى بيشـترين

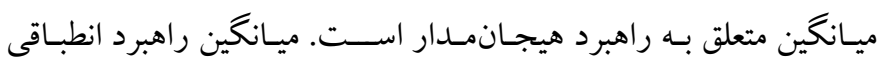

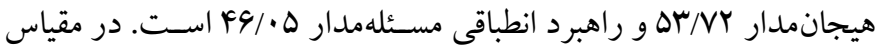
راهبردهـاى تنظيم هيجان، بيشـترين ميانخين مربوط به راهبردهاى تنظيم هيجان منفى اســت. در مقياس درماندكى روانشــناختى نيز افســردكى داراى بيشترين ميانكين و تنيدگى داراى كمترين ميانكين است. همجنين كشــــــى و جهولكى تمـام متغيرهـا در بـازه (Y و Y-) قرار دارد كــ نشــاندهنده توزيع نرمال متغيرها از لحاظ جولكى و كشــيدگى اســت. ضرايب همبستكى بين متغيرهاى يثروهش در جدول بارائه شده است. جدول r: ضرايب همبستكى راهبردهاى مقابلهاى و تنظيم هيجان با درماند مكى روانشناختى

\begin{tabular}{|c|c|c|c|}
\hline تنيدكى & اضطراب & افسردگى & متغيرها \\
\hline$-\cdot / r^{\text {漛 }}$ & $-\cdot / \cdot M$ & $-\cdot / \mathrm{M}^{\text {繁 }}$ & راهبرد حل مسئلهمدار \\
\hline$\cdot / 19^{* * *}$ & $\cdot / \mu^{* * * *}$ & .1 .9 & راهبرد هيجانمدار \\
\hline$-\cdot / \cdot r$ & $\cdot / 14^{*}$ & $\cdot / \cdot \wedge$ & راهبرد تنظيم هيجان منفى \\
\hline$-\cdot / \cdot 9$ & $-\cdot / Y *$ & $-\cdot / \Upsilon \Delta^{* * *}$ & راهبرد تنظيم هيجانات \\
\hline
\end{tabular}


جدول r: نتايج ركرسيون و تحليل واريانس افسردگى بر اساس راهبردهاى مقابلهاى و راهبردهاى تنظيم هيجان

\begin{tabular}{|c|c|c|c|c|c|c|c|}
\hline سطح معنادارى & $\mathbf{t}$ & $\beta$ & سطح معنادارى & $\mathbf{F}$ & $\mathbf{R 2}$ & $\mathbf{R}$ & \\
\hline$\cdot \cdots$ & -r/AKF & $-\cdot / r \Delta V$ & $\cdot \cdots$ & $\mid F / v \cdot r$ & .1 .94 & $\cdot / r \Delta$ & راهبرد تنظيم هيجان مثبت \\
\hline$\cdot / \ldots$ & $-r / \Delta \wedge \varphi$ & פשץ. & $\ldots$ & 1. $/ J_{\mathcal{F}}$ & .1 .9 & . & راهبرد تنظيم هيجان مثبت \\
\hline .1 .19 & $-Y / T 49$ & & & & & & راهبرد حل مسئله مدار \\
\hline$\cdot / \ldots$ & $-r / \Delta V \mid$ & & & & & & راهبرد نظيم هيجان مثبت \\
\hline$\cdot / \cdots$ & $-r / \Delta \Delta F$ & $-\cdot / \mid \Delta \wedge$ & $\cdot \cdots$ & $1 . / 189$ & . & 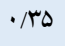 & راهبرد حل مسئله مدار \\
\hline$\cdot / \mu r$ & $r / .1 V$ & & & & & & راهبرد هيجان مدار \\
\hline
\end{tabular}

افسردگى توسط اين سه متغير به سا درصد رسيد. نتايج تحليل واريانس

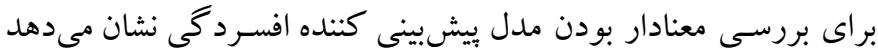

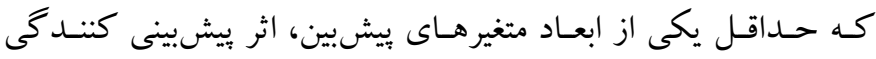

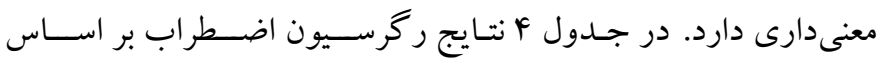

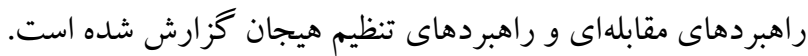

نتـايج ارائه شـــه در جدول بمدر ارتباط با خردهمقياس افسـردكى نشــان داد كـه در كام اول متغير راهبرد تنظيم هيجان مثبت بهعنوان

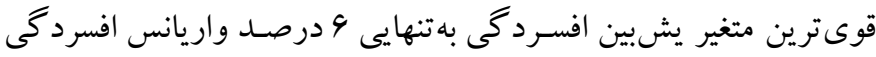

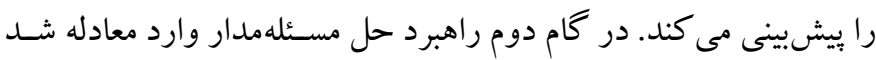

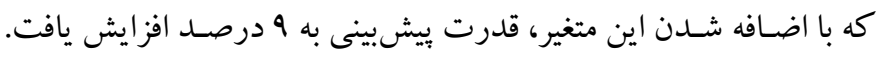

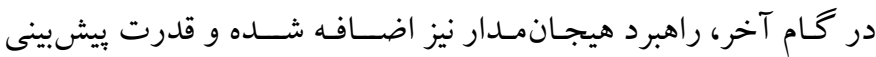

جدول ع: نتايج ركرسيون اضطراب بر اساس راهبردهاى مقابلهاى و راهبردهاى تنظيم هيجان

\begin{tabular}{|c|c|c|c|c|c|c|c|}
\hline سطح معنادارى & $\mathbf{t}$ & $\boldsymbol{\beta}$ & سطح معنادارى & $\mathbf{F}$ & $\mathbf{R 2}$ & $\mathbf{R}$ & \\
\hline.$/ \cdot 1$ & $-r / 010$ & $-\cdot / Y M V$ & $\cdot / \cdot \cdot 1$ & $I r / r \Delta V$ & $\cdot / \cdot \Delta$ & $\cdot / \pi$ & راهبرد تنظيم هيجان مثبت \\
\hline$\% \cdots$ & $-r / V Y \Lambda$ & $-\cdot /$ YFF & \multirow{2}{*}{$\% \cdots$} & \multirow{2}{*}{$i r / r v}$. & \multirow{2}{*}{.$/ 11$} & \multirow{2}{*}{ 每/ } & راهبرد تنظيم هيجان مثبت \\
\hline$\% \cdots$ & $r / 99 r$ & - MFY & & & & & راهبرد حل مسئلهمدار \\
\hline$\% / \cdot 1$ & -r/frr & $-\cdot / Y Y I$ & \multirow{3}{*}{$\% \cdots$} & \multirow{3}{*}{ IY/DYF } & \multirow{3}{*}{$\cdot / 10$} & \multirow{3}{*}{$\cdot / 4 q$} & تنظيم هيجان مثبت \\
\hline$\% \cdots$ & F/vas & $\cdot /$ TFq & & & & & راهبرد هيجانمدار \\
\hline$\% r$ & $-r / 119$ & $-\cdot / r Y A$ & & & & & راهبرد حل مسئله مدار \\
\hline.$/ 11$ & $-r / \Delta V r$ &.$- / 191$ & \multirow{4}{*}{$\cdot \cdots$} & \multirow{4}{*}{ Ir/rar } & \multirow{4}{*}{$\cdot / 19$} & \multirow{4}{*}{$\cdot / A q$} & تنظيم هيجان مثبت \\
\hline$\% \cdots$ & $\Delta / \Delta ৭ \Delta$ & $\cdot / 419$ & & & & & راهبرد هيجانمدار \\
\hline$\% \cdots$ & -r/ar. & $-\cdot / r a r$ & & & & & راهبرد حل مسئلهدار \\
\hline$\% r$ & $r / l \Delta V$ &.$/ Y 10$ & & & & & تنظيم هيجان منفى \\
\hline
\end{tabular}

كام آخر نيز تنظيم هيجان منفى وارد معادله شـــ كه در نهايت توانسـتند 19 درصـد از واريانس اضطراب را بيشبينى كنند. همجنين نتايج تحليل واريانس براى بررسى معنادار بودن مدل بيشبينى كننده اضطراب نشان

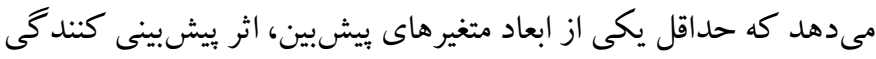

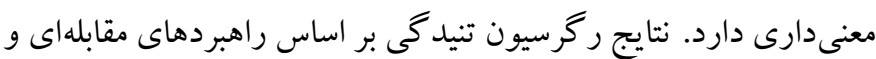
راهبردهاى تنظيم هيجان در جدول ه گزارش شده است.
همانطور كه در جدول F مشـاهده مىشود در كام اول متغير راهبرد تنظيم هيجان مثبت بهعنوان قوى ترين متغير ويشبين اضطراب بهتنهايى هـ

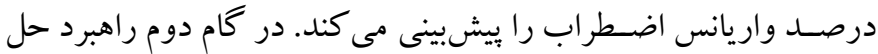

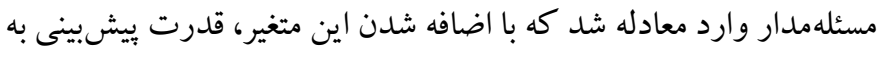
11 اردصد افزايش يافت. در كام بعدى، راهبرد هيجانمدار نيز اضافه شده و قدرت بيشبينى اضطراب توسط اين سه متغير به ها درصد رسيد. در 
جدول 0: نتايج ركرسيون تنيدكى بر اساس راهبردهاى مقابلهاى و راهبردهاى تنظيم هيجان

\begin{tabular}{|c|c|c|c|c|c|c|c|}
\hline سطح معنادارى & $\mathbf{t}$ & $\boldsymbol{\beta}$ & سطح معنادارى & $\mathbf{F}$ & $\mathbf{R 2}$ & $\mathbf{R}$ & \\
\hline.$/ . \cdot 1$ & -r/fFF & - & $\cdot / \cdot \cdot 1$ & $11 / \wedge \Delta \Lambda$ & $\cdot / \cdot \Delta$ & $\cdot / r \mu$ & راهبرد حل مسئلهمدار \\
\hline $\begin{array}{l}\cdot / \cdots \\
. / \cdots\end{array}$ & $\begin{array}{l}-\Delta / A \Lambda r \\
\Delta / \Delta Q V\end{array}$ & $\begin{array}{l}-\cdot / F Y I \\
\cdot / R M Q\end{array}$ & $\cdot / \cdots$ & Yr/rVq & $\cdot / I V$ & $\cdot / A Y$ & راهبرد هيجانمدار حسئلهمدار \\
\hline
\end{tabular}

كه مقصر دانستن خود، نشخوار فكرى، و فاجعبار تلقى كردن بهعنوان

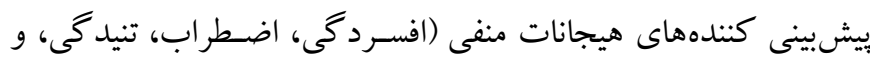
خشـم) عمل مى كنند. بررسى متون و مطالعات روانشـناختى نيز نشـان مى دهد كه تنظيم هيجان، عامل مهمى در تعيين سلامتى و داشتن عملكرد مهرد موفق در تعاملات اجتماعى و بينفردى اسـت (Y)) و ضسعف در آن با

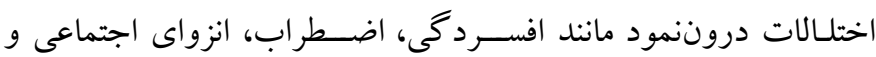

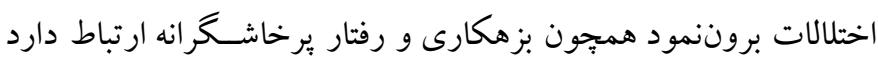

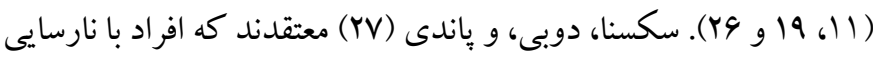
در تنظيم هيجان، از تعارضـات بينفردى اجتناب مى كنند و براى بيان

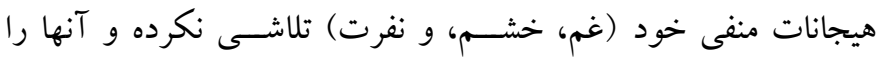

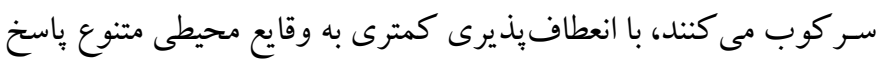

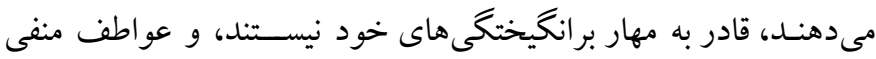
زيادى را تجربه مى كنند؛ در نتيجه از سـلامت جسـمى و روانى كمترى

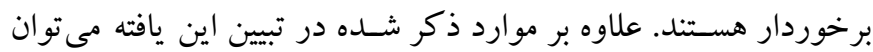
كفت كه توانايى فهم، مديريت و تنظيم هيجانها و عواطف، از اصول

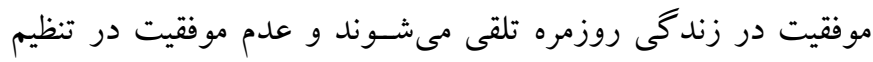
هيجـانها و اسـتفاده از راهبردهاى ناكارآمد همجيون فرونشــانى و اجتناب، مى تواند بيامدهاى منفى از جمله سطوح بياين سـلامت روانى را براى فرد به دنبال داشته باشد

امروزه بر خلاف نظريههاى اوليه، بر مفيد بودن هيجان در رفتارها

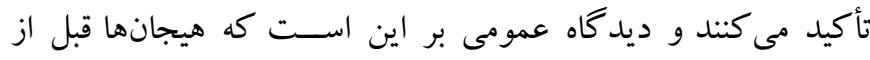

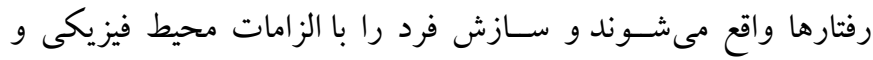

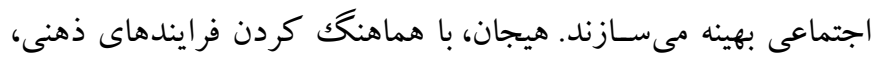

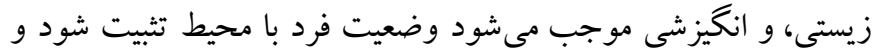
ضـمن تجهيز وى با پاســخهاى ويثزه و مناسـب با مسـائل، در نهايت موجب بقاى جسمانى و اجتماعى او مىشود (1)؛؛ بنابر اين ناكار آمدى بـ بـ در تنظيم هيجان با تعدادى از بيامدهاى جسـمانى، اجتماعى، روانى، و
بر اسـاس نتايج جدول ه متغيرهاى راهبرد حل مسـئلهمدار و هيجان

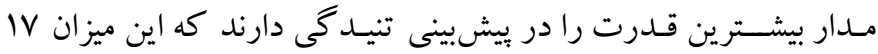
درصد است. راهبردهاى تنظيم هيجان نقش مؤثرى در بيشبينى اين متغير

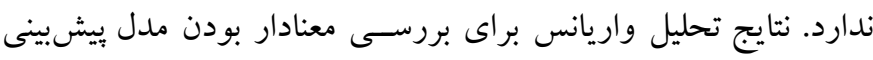

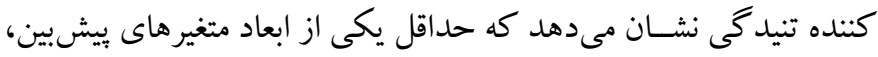
اثر بيشبينى كنند

بحث و نتيجه كيرى اين مطالعه با هدف بررسى نقش راهبردهاى تنظيم هيجان و راهبردهاى

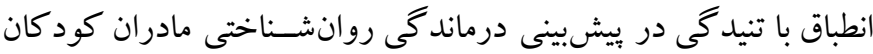

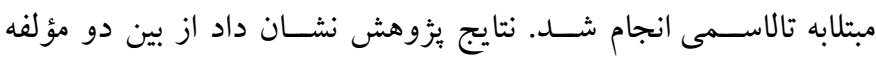
راهبردهـاى تنظيم هيجـان، راهبردهاى تنظيم هيجان مثبت، رابطه معنادار

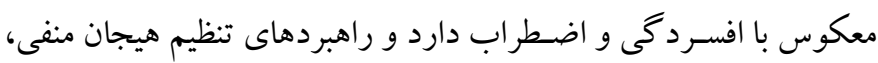

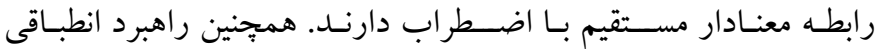

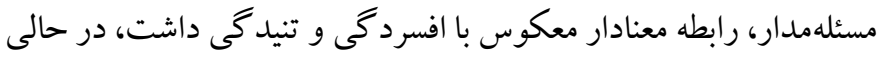

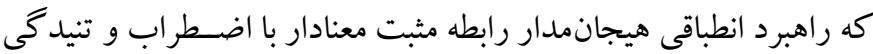

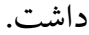

نتـايج بثزوهش حـاضــر در ارتبـاط بـا راهبردهـاى تنظيم هيجان، با

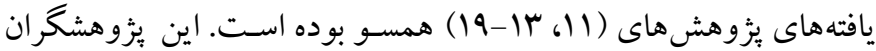
در مطالعـات خود دريـافتنـد كـه راهبردهاى كار آمد تنظيم هيجان، ارتباطى منفى و راهبردهـاى نـاكار آمد تنظيم هيجان ارتباطى مثبت با دهري

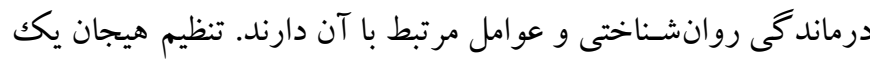

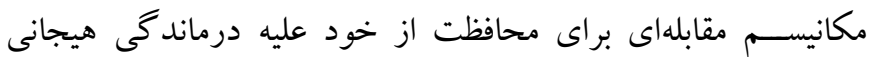
مرتبط با موقعيت هاى آسيبزا است (19). مارو كوئين و نولن - هو كسما

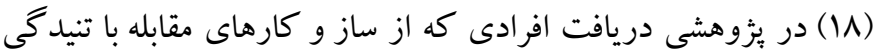

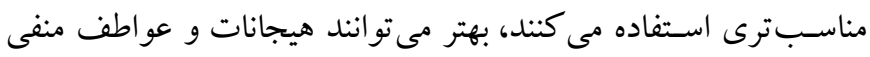

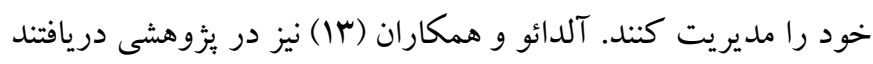


از موقعيت، ممكن اسـت در كاهش تنش در كو تاهمدت مؤثر باشــد، در مقابل اسـتفاده از انواع روشهاى مقابلهاى مانند تدابير متمركز بر مسـئله،

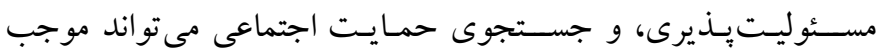

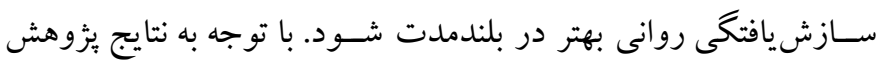

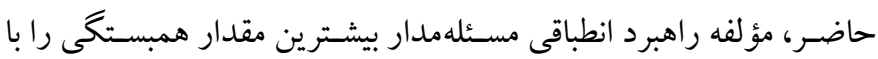

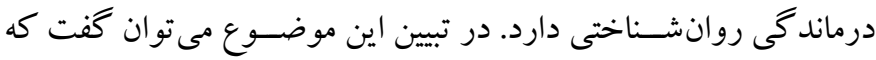

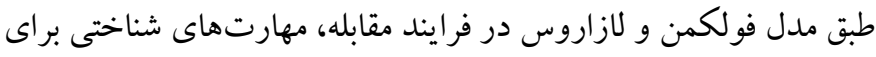

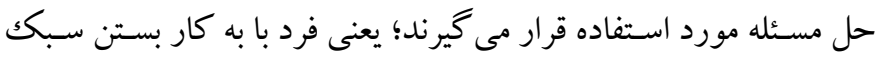
مقابله مسـئلهمدار از مهارتهاى شـناختى براى حل مسئله استفاده مى كند. بدين ترتيب راههاى مقابله با مشكل مستقيماً بررسى مى شوند و معمولاً با

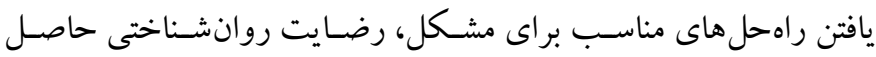
مىشود. از سوى ديخر اين وضعيت باعث نظم و انسجام فكرى مى شود و و

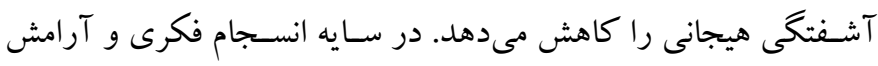

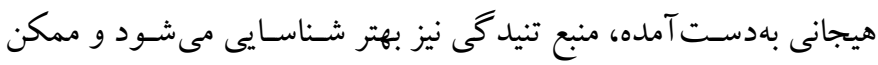

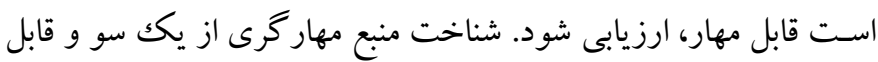

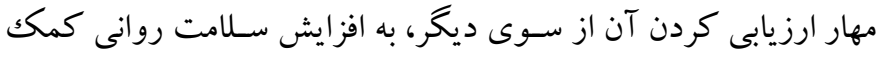

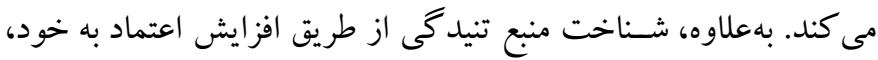

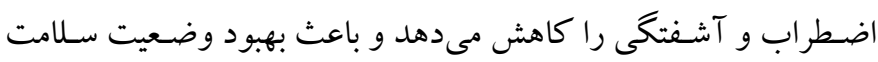

$$
\text { روانى مىشود (YF). }
$$

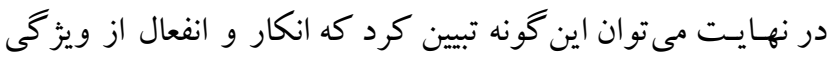
افرادى اسـت كـه از راهبرد مقـابلهاى ناكار آمد هيجانمدار اســفاده

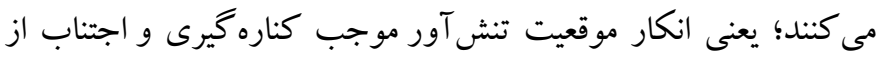

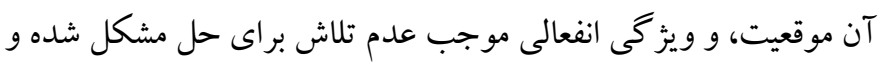

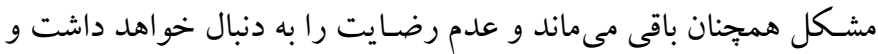
در نتيجه ميزان درماندگى روانشناختى با افزايش استفاده از راهبرد مقابله اي هيجانمدار افزايش يافته و با استفاده از راهبرد مسئلهمدار كاهش مى

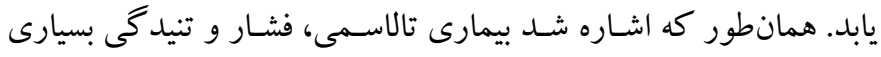

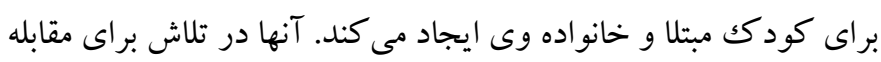

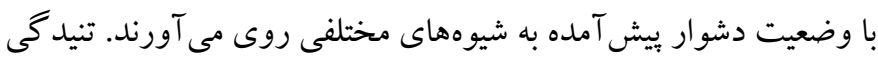

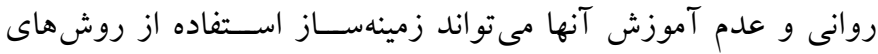

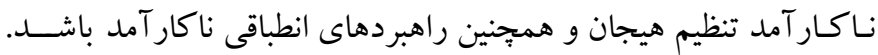

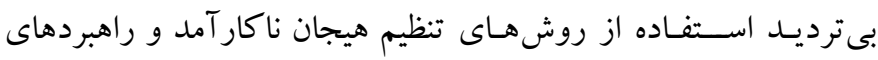

فيزيولوزيكك مرتبط است و در نتيجه نارسايى در آن، كاهش سطوح سـلامت روانى و افزايش مشـكلاتى همجيون افسـردكى و ســاير ابعاد درماندگى روانشناختى است. همجنين با توجه به آنكه هيجانها از نظر إنى

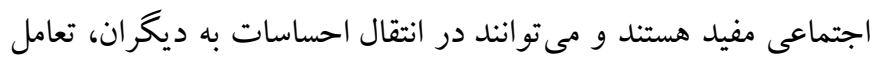

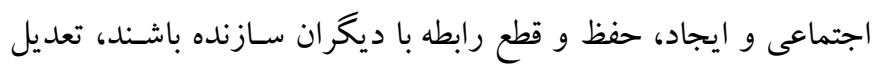
و تنظيم آنها مى تواند نقش مؤثرى در افزايش سطوح سـلامت روانى از

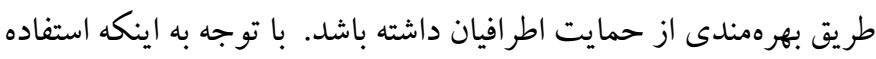

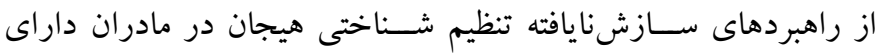

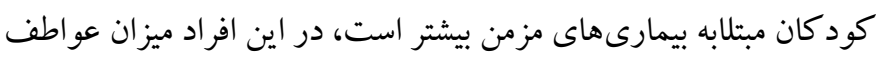

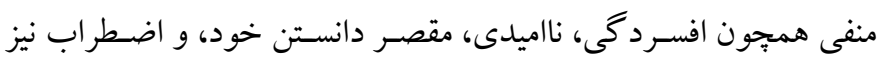

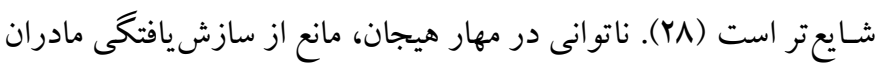

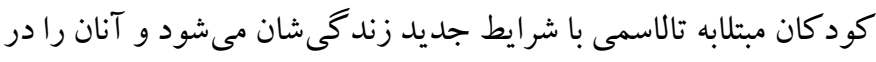

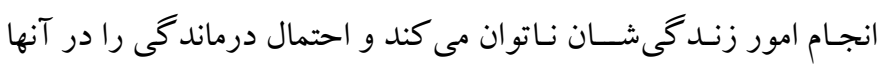

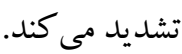

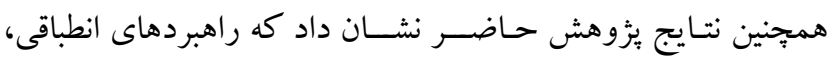

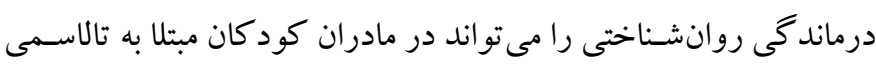

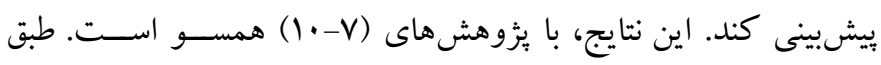

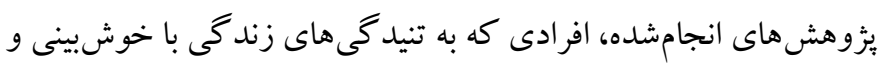

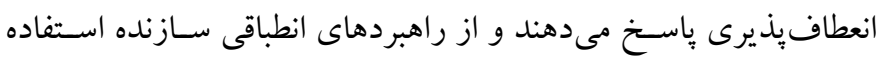

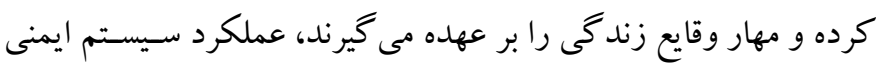

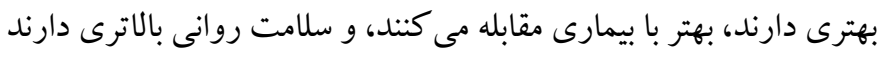

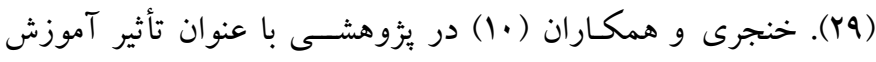

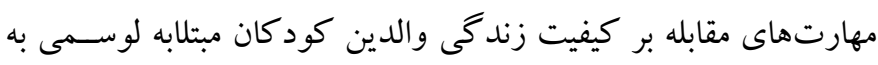

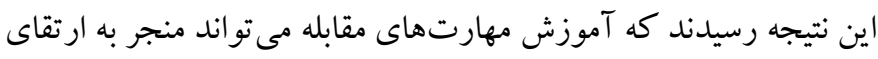

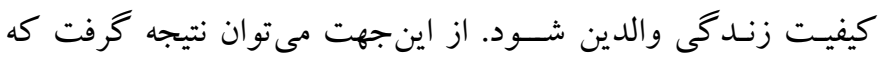

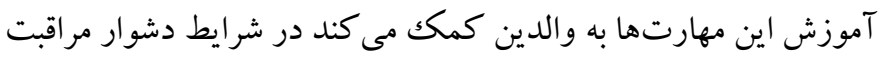

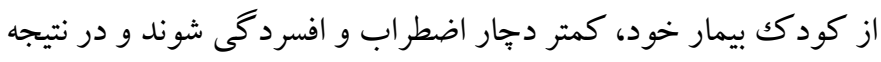

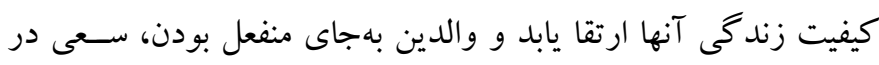

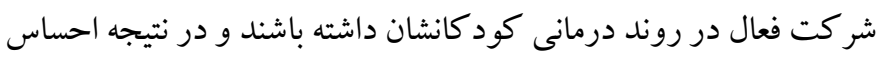

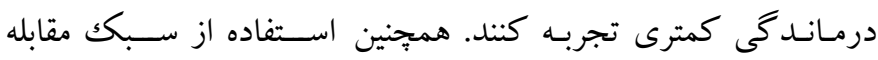
مسئلهمحور با احسـاس خودمهار گرى و خود كار آمدى بيشتر تو أم است. به اين ترتيب هرجند مقابله هيجانى مانند ناديده انگًاشتن، گريز و و اجتناب 
بيشـنهاد مىشـود كه نهادهاى مسـول، شـرايط مداخله هاى روانشناختى

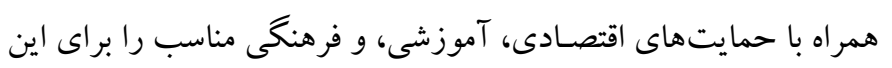

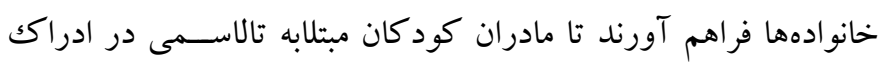

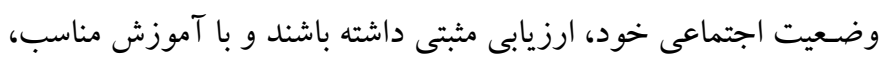
اين خانوادهها را در انتخاب سبككهاى تنظيم هيجان و راهبردهاى انطباقى

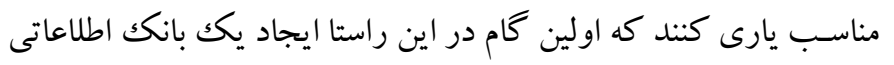

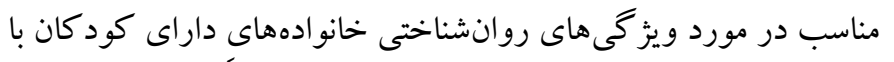

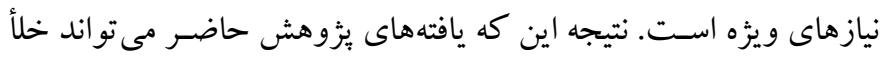

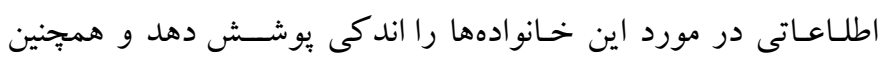

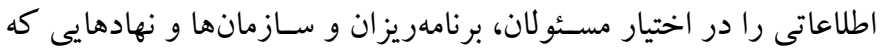

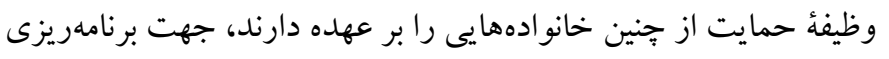

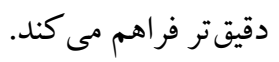

تشـكر و قدردانى: اين مطالعه به طور مسـتقل انجام شـــه اسـت و حاصـل

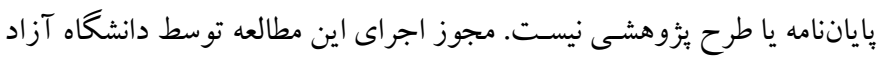

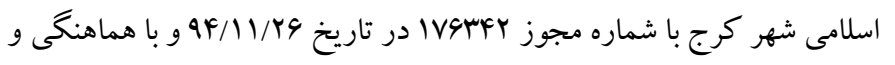

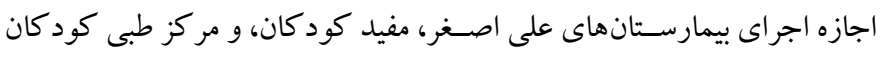

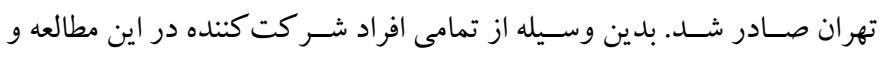

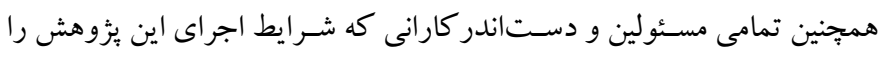

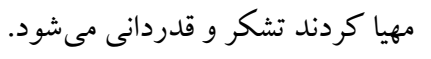
تضـاد منافع: بلدينوسيله نويسـنده برزوهش حاضـر يادآور مىشـود اثر حاضر

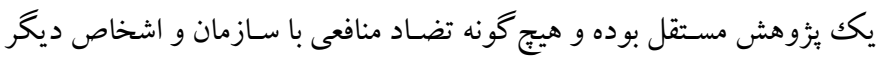

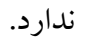

انطباقى نامناسـب، نه تنها به بهبود وضسعيت كمكى نمى كند، كه مى تو اند

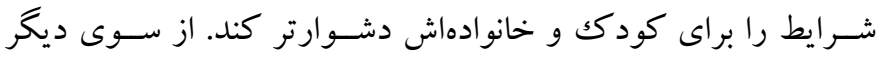

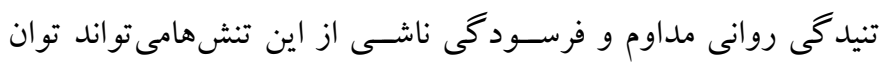

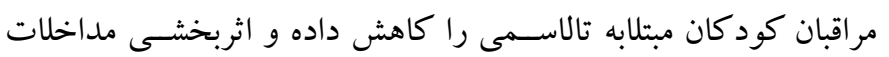
درمانى را نيز تحت تأثير قرار دهد. آموزش والدين كودكان مبتلابه تالاسـمى و به خصوص مادران آنها (كه مهمترين مر اقبان اين كود كان به شـمار مىروند) در اسـتفاده از راهبردهاى انطباقى كار آمدتر و همجينين

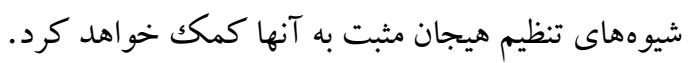

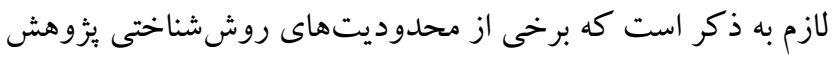

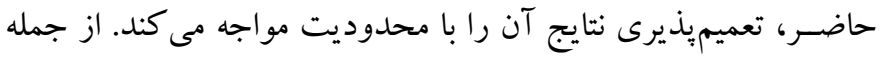

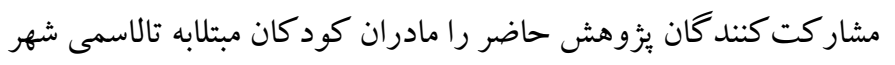

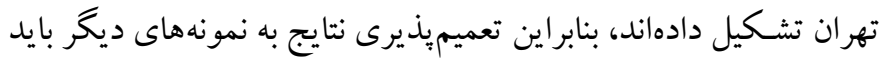

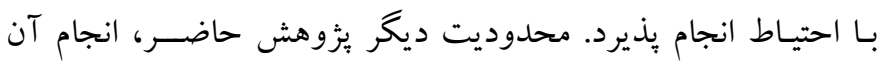
بهصورت مقطعى استـ؛ بنابراين توصيه مى بـود، بررسى طولى وضعيت

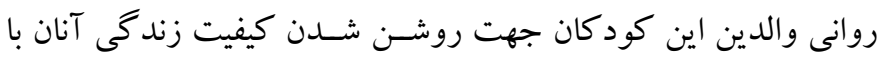

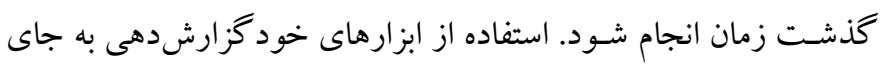
بررسى رفتار واقعى ممكن اسـت، مشـار كت كنند كان را به اسـتفاده از

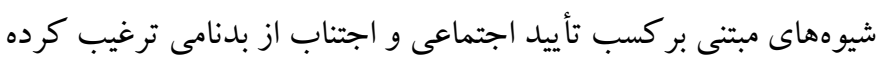

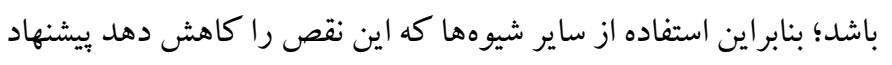

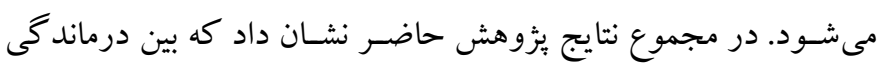
روانشـناختى با راهبردهاى تنظيم شـناختى هيجان و همجنين راهبردهاى تردي

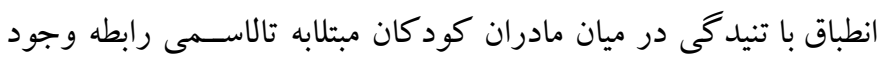

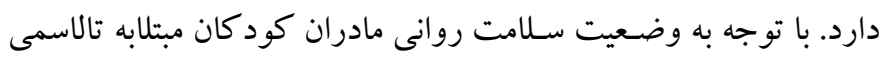




\section{References}

1. Miri M, Tabrizi Namini M, Hadipour Dehshal M, Sadeghian Varnosfaderani F, Ahmadvand A, Yousefi Darestani S, et al. Thalassemia in Iran in last twenty years: the carrier rates and the births trend. Iranian Journal of Blood and Cancer. 2013; 6(1): 11-17. [Link]

2. Nasiri M, Hosseini H, Shahmohammadi S. Mental health status in patients with Thalassemia major in Iran. Journal of Pediatrics Review. 2014; 2(1): 55-61. [Link]

3. Rafiee $H$. Introduction to psychology. Tehran: Arjomand; 2003, pp: 57-62. [Persian].

4. Seyf AA. Change in behavioral and behavioral therapy theories and methods. Tehran: Duran; 1379, pp: 114132. [Persian].

5. Roger D, Najarian B. The construction and validation of a new scale for measuring emotion control. Pers Individ Dif. 1989; 10(8): 845-853. [Link]

6. Ben-Zur H. Coping styles and affect. Int J Stress Manag. 2009; 16(2): 87-101. [Link]

7. SeyedTabaee R, Rahmatinejad P, Mohammadi D, Etemad A. The role of coping strategies and cognitive emotion regulation in well-being of patients with cancer. The Journal of Qazvin University of Medical Sciences. 2017; 21(2): 41-49. [Persian]. [Link]

8. Ebadi Vashmesara M, Khademi A. The study of emotional intelligence and coping styles and the evaluation of their interactive relationship in case of cancerous patients. Medical Journal of Tabriz University of Medical Sciences and Health Services. 2015; 36(6): 54-61. [Persian]. [Link]

9. Shalani B, Alimoradi F, Sadeghi S. The relationship between stress coping strategies and social skills with aggression in deaf female students. Pajouhan Scientific Journal. 2018; 16(2): 11-18. [Persian]. [Link]

10. Khanjari S, Oskouie F, Eshaghian Dorche A, Haghani $\mathrm{H}$. Quality of life in parent of children with leukemia and its related factors. Iran Journal of Nursing. 2013; 26(82): 1-10. [Persian]. [Link]

11. Gross JJ. Handbook of emotion regulation. Second edition. New York: Guilford Publications; 2015, pp: 98-102. [Link]

12. Garnefski N, Kraaij V, Spinhoven P. Negative life events, cognitive emotion regulation and emotional problems. Pers Individ Dif. 2001; 30(8): 1311-1327. [Link]

13. Aldao A, Jazaieri H, Goldin PR, Gross JJ. Adaptive and maladaptive emotion regulation strategies:
Interactive effects during CBT for social anxiety disorder. J Anxiety Disord. 2014; 28(4): 382-329. [Link]

14. Azizi A, Mir Derikvand F, Mohamadi J. Comparison of personality factors and cognitive emotional regulation in gastric and lung cancer patients and normal subjects. Razi Journal of Medical Sciences. 2015; 22(132): 1-9. [Persian]. [Link]

15. Salehi A, Mazaheri Z, Aghajani Z, Jahanbazi B. The role of cognitive emotion regulation strategies in the prediction of depression. Knowledge \& Research in Applied Psychology. 2015; 16(1): 108-117. [Persian]. [Link]

16. Bahrami B, Bahrami A, Mashhadi A, Kareshki H. The role of cognitive emotion-regulation strategies in the quality of life of cancer patients. Medical Journal of Mashhad University of Medical Sciences. 2015; 58(2): 96-105. [Persian]. [Link]

17. Kim HY, Page T. Emotional bonds with parents, emotion regulation, and school-related behavior problems among elementary school truants. J Child Fam Stud. 2013; 22(6): 869-878. [Link]

18. Marroquín B, Nolen-Hoeksema S. Emotion regulation and Dpressive symptoms: close relationships as social context and influence. J Pers Soc Psychol. 2015; 109(5): 836-855. [Link]

19. Ghasempour A, Akbari E, Azimi Z, Ilbeygi R, Hassanzadeh S, Akbari E. Predicting obsessivecompulsive disorder on the basis of emotion regulation and anxiety sensitivity. Zahedan Journal of Research in Medical Sciences. 2013; 15(2): e93122. [Link]

20. King LA. Ambivalence over emotional expression and reading emotions in situations and faces. J Pers Soc Psychol. 1998; 74(3): 753-762. [Link]

21. Sharifi Daramadi P. Psychology of exceptional children. Tehran: Psychoanalysis; 2002, pp: 43-51. [Persian].

22. Lovibond PF, Lovibond SH. The structure of negative emotional states: comparison of the depression anxiety stress scales (DASS) with the beck depression and anxiety inventories. Behave Res Ther. 1995; 33(3): 335-343. [Link]

23. Asghari A, Saed F, Dibajnia P. Psychometric properties of the depression anxiety stress scales-21 (DASS-21) in a non-clinical Iranian sample. Int $\mathbf{J}$ Psychol. 2008; 2(2): 82-102. [Link]

24. Ma'arefvand M, Khatamsaz Z. Coping strategies of the parents of the children with cancer. Quarterly Journal of Social Work. 2014; 3(3): 3-9. [Persian]. [Link] 
25. Lazarus RS, Folkman S. Coping and adaptation. Gilford Press; 1985, pp: 56-81.

26. Tortella-Feliu M, Balle M, Sesé A. Relationships between negative affectivity, emotion regulation, anxiety, and depressive symptoms in adolescents as examined through structural equation modeling. J Anxiety Disord. 2010; 24(7): 686-693. [Link]

27. Saxena P, Dubey A, Pandey R. Role of emotion regulation difficulties in predicting mental health and well-being. SIS Journal of Projective Psychology \& Mental Health. 2011; 18: 147-155. [Link]

28. Nolen-Hoeksema S, McBride A, Larson J. Rumination and psychological distress among bereaved partners. Journal of Personality and Social Psychology. 1997; 72(4): 855-862. [Link]

29. Coyne G. An investigation of coping skills and quality of life among single sole supporting mothers. Int $\mathbf{J}$ Anthropol. 2003; 18(3): 127. [Link] 